\title{
CHLORINE DEMAND AND BACTERIAL ABUNDANCE OF SHRIMP POND WATER UNDER DIFFERENT SUSPENDED SOLID CONCENTRATIONS
}

\author{
Husnah*)
}

\begin{abstract}
An experiment has been conducted to evaluate the chlorine demand and efficacy of 6 chlorine concentrations in brackish pond water, to control indigenous bacteria in shrimps pond. Pond water (salinity: 3-4 ppt) at three different levels of total suspended solids (TSS) $(26,69$, and 114 $\mathrm{mg} / \mathrm{L}$ ) were collected in glass jars and treated with chlorine concentrations of $0,5,10,20,30$, and $50 \mathrm{mg} / \mathrm{L}$, respectively. Residual chlorine concentration was determined at $0,12,24$ hours, and subsequently every day for 7 days. The chlorine demand of the water was then calculated. Total organic carbon and total ammonia nitrogen were measured in the beginning and at the end of the experiment. Chlorine demand of the shrimp pond water was significantly affected by initial TSS concentration of $114 \mathrm{mg} / \mathrm{L}$, completed in 24 hours, as compared to 7 days in pond water with TSS concentrations of 69 and $29 \mathrm{mg} / \mathrm{L}$. Complete bacterial inactivation in pond water with TSS concentration of $114 \mathrm{mg} / \mathrm{L}$ was detected, immediately after the application of chlorine concentration of 50 $\mathrm{mg} / \mathrm{L}$. In pond water with TSS levels of $69 \mathrm{mg} / \mathrm{L}$ and $29 \mathrm{mg} / \mathrm{L}$, the inactivation of the bacteria was observed 48 hours after the application of chlorine at $50 \mathrm{mg} / \mathrm{L}$ and $30 \mathrm{mg} / \mathrm{L}$, respectively. Chlorine concentration of $50 \mathrm{mg} / \mathrm{L}$ could deactivate bacteria in pond water with TSS level of $29 \mathrm{mg} / \mathrm{L}$ for up to 96 hours.
\end{abstract}

KEYWORDS: residual chlorine, chlorine demand, total organic carbon, suspended solid, bacteria, shrimp pond

\section{INTRODUCTION}

Chlorination has been recently practiced in shrimp farming directly to grow-out ponds or reservoir ponds (Kongkeo, 1995; Boyd, 1996). Shrimp farmers apply chlorine at a dose rate of 180 to $300 \mathrm{~kg} / \mathrm{ha}$ or 18 to 30 $\mathrm{mg} / \mathrm{L}$ to eliminate pathogenic microorganisms and their carriers in the pond (Kongkeo, 1995; Hedge et al., 1996), and at $0.1 \mathrm{mg} / \mathrm{L}$ for controlling algal bloom (Boyd \& Massaut, 1999). When chlorine dissolves in pond water, it forms free residual chlorine. Part of this free chlorine which reacts with organic and oxidizable substances is referred as chlorine demand. The residual oxidize damage nucleic acid and/or protein of microorganisms and cause lethal effects (Archer et al., 1997; Chanratchakool, 1995).

High concentrations of organic matter and suspended solid which often occur in water and accumulate in the bottom sediment of shrimp ponds (Hopkins et al, 1993; Dierberg \& Kiattisimkul, 1996), cause high chlorine demand and reduce the efficacy of chlorine. As a result, more chlorine is required to disinfect target organisms. It has been shown that the chlorine dose required to inactivate bacteria in water increase 100 times in the presence of $50 \mathrm{mg} / \mathrm{L}$. organic matter at neutral pH condition (Harakeh, 1986).
Little information is available on chlorine demand and its effect on aquatic organisms of shrimp ponds, despite the fact that chlorine is applied routinely to most shrimp ponds in Thailand. The present study aims to determine chlorine demand of pond water, and the effective chlorine dose required to inactivate those organisms.

\section{MATERIALS AND METHODS}

Water samples were collected from shrimp ponds with different TSS concentrations of i.e., 29, 69, and $114 \mathrm{mg} / \mathrm{L}$ which were obtained at 16-day, 2.5-month, and 3.5-month cultured period, respectively. The ponds were located at Samutprakan province, in Thailand and were treated using similar methods. Before starting the culture period, ponds bottom was dried for one to two months till the soil was cracked and then filled with freshwater coming from a canal nearby. The pond water was then mixed with brine water (100-120 $\mathrm{ppt}$ ) to get $5 \mathrm{ppt}$ water and then stocked with 15-dayold (PL15) shrimp larvae of black giant tiger shrimp (Penaeus monodon) at stocking density of 43 shrimp/ $\mathrm{m}^{2}$. The shrimps were cultured for three to five months. During the culture period, concentration of total suspended solids and TAN ranged from $29 \mathrm{mg} / \mathrm{L}$ and 1.04 $\mathrm{mg} / \mathrm{L}$ (at the start of the culture) to $140 \mathrm{mg} / \mathrm{L}$ and 1.48

Researcher at the Research Institute for Openwater Fisheries, Palembang 
$\mathrm{mg} / \mathrm{L}$ (closed to the harvest time) respectively. Two hundred liters water sample were taken from the whole column of the pond by using column water sampler made from PVC with $0.1 \mathrm{~m}$ diameter connected to hydraulic-pump. The water samples were then kept separately in 250-L plastic container, brought to the laboratory, and aerated

The water sample was mixed homogeneously and distributed to 12 glass jars with water volume of $9 \mathrm{~L}$ each, and aerated overnight to increase the dissolved oxygen (DO) lend up to at least $5 \mathrm{mg} / \mathrm{L}$. The water was then treated with different chlorine concentrations by dissolving alloted concentrations of calcium hypochlorite or High Test Hypochlorite (HTH) (with 65\% active ingredient) with $25-\mathrm{mL}$ distilled water. All jars were placed out doors in a roofed place with temperature ranging from 27.9 to $28.0^{\circ} \mathrm{C}$

The experiment was set up in a factorial design with 6 levels of active chlorine concentrations 10,5 , $10,20,30$ and $50 \mathrm{mg} / \mathrm{L}$ ), 3 levels of TSS concentrations $(29,69$ and $114 \mathrm{mg} / \mathrm{L})$, in duplicate.

Water $\mathrm{pH}$ was measured before and 12, 24, 48, 96 , and 168 hours after chlorine application using a digital pH-meter (Hanna HI8424). Total organic carbon (TOC) and total ammonia nitrogen (TAN) were measured at 0 and 168 hours ( 7 days) after chlorine application by taking $150-\mathrm{mL}$ of water sample from each jar. Total organic carbon and total ammonia nitrogen were analyzed by using Combustion Infra Red and Phenate methods (APHA, 1992).

About $100-\mathrm{mL}$ water sample was collected from each treatment at 0,12, 24 hours and subsequently every day until the total residual chlorine in the water was zero, which was about 7 days resulting a preliminary study, for free and total residual chlorine (FRC and TRC) analysis. Total residual chlorine is the sum of free residual chlorine and the combined residual chlorine, amount of free chlorine reacts with nitrogen compound. The analysis was done by using N,N-diethyl-p-phenylenediamine (DPD) ferrous titrimetric method. Bacterial abundance was measured by taking $20-\mathrm{mL}$. water sample from each treatment, kept in $20-\mathrm{mL}$ sterilized vials and then directly analyzed by using plate count method with droplet modification (APHA, 1992). Bacteria abundance was measured at $0,48,96$, and 168 hours.

Chlorine demand was calculated by subtracting the amount of chlorine applied and the total residual chlorine. Chlorine demand and bacteria abundance were analyzed by two-way analysis of variance at $a=0.05$ (Box et al., 1978). Significant difference among treatments were analyzed with Tuckey HSD method, using a statistical software (Statistical version 5.0)

\section{RESULTS}

\section{Chlorine demand}

Free and total residual chlorine (FRC and TRC) increased a chlorine concentrations were applied and decreased with TSS concentrations and time of observation (Figure $1 \& 2$ ). FRC and TRC concentrations of pond water with TSS concentration of $29 \mathrm{mg} /$ L (16-day old pond), were higher than those with TSS concentration of 69 and $114 \mathrm{mg} / \mathrm{L}$ ( 2.5 and 3.5 -month old ponds) respectively $(P<0.01)$. FRC concentration immediately after chlorine application $(0 \mathrm{~h})$ in pond water with TSS concentration of 29,69 , and $114 \mathrm{mg} /$ $\mathrm{L}$ were 0.16 to $34.41 \mathrm{mg} / \mathrm{L}, 0.08$ to $26.04 \mathrm{mg} / \mathrm{L}$, and 0.8 to 20.93 , respectively. FRC concentration reduced to less than $0.1 \mathrm{mg} / \mathrm{L} .24$ hours after chlorine application in all treatments, except at chlorine treatment of $50 \mathrm{mg} / \mathrm{L}$ and $29 \mathrm{mg} / \mathrm{L}$ TSS. FRC concentration in chlorine treatment of $50 \mathrm{mg} / \mathrm{L}$, could not be detected in pond water with TSS concentration of $114 \mathrm{mg} / \mathrm{L}$ and was recorded $69 \mathrm{mg} / \mathrm{L}, 48$, and 168 hours after chlorine exposure, and about $0.32 \mathrm{mg} / \mathrm{L}$ in pond water with TSS of $29 \mathrm{mg} / \mathrm{L}$

Consumption of chlorine was affected by initial TSS concentration (Figure 3). Chlorine consumption in pond water with TSS concentration of $114 \mathrm{mg} / \mathrm{L}$ was faster than that in pond water with TSS concentration of 69 and $29 \mathrm{mg} / \mathrm{L}$, and the consumption was completed within 24 hours exposure. While in pond water with TSS concentration of 69 and $29 \mathrm{mg} / \mathrm{L}$, the consumption was completed within 168 hours. Figure 3 also shows that chlorine consumption in pond water with TSS of $69 \mathrm{mg} / \mathrm{L}$ was faster than in pond water with TSS of $29 \mathrm{mg} / \mathrm{L}$. Except at 168 hours measurement, chlorine consumption in pond water with TSS of 114 $\mathrm{mg} / \mathrm{L}$ was significantly higher than in pond water with TSS of $69 \mathrm{mg} / \mathrm{L}$ and $29 \mathrm{mg} / \mathrm{L}(\mathrm{P}<0.01)$.

Two-way analysis of variance reveales a significant difference in chlorine consumption among chlorine concentration treatments during the experimental period. The chlorine consumption increased with increasing the chlorine concentrations $(P<0.01)$.

\section{Bacterial abundance}

Concentration of TSS and FRC affected the inactivation of bacteria. Increasing TSS and decreasing chlorine concentration, reduced bacterial inactivation (Figure 4). Immediately after chlorine application (0 h) bacterial inactivation in pond water with TSS concentration of $29 \mathrm{mg} / \mathrm{L}$ was higher than in pond water with TSS of 69 and $114 \mathrm{mg} / \mathrm{L}$. $(P<0.01)$. Chlorine concentrations of 30 and $50 \mathrm{mg} / \mathrm{L}$ produced higher bacterial inactivation than other chlorine concentrations. At the TSS concentration of $29 \mathrm{mg} / \mathrm{L}$, a chlorine concen- 
tration as low as $10 \mathrm{mg} / \mathrm{L}$ with FRC concentration of $1.16 \mathrm{mg} / \mathrm{L}$, could completely inactivate bacteria. To achieve the same result in pond water with TSS concentration of 69 and $114 \mathrm{mg} / \mathrm{L}$, at least $30 \mathrm{mg} / \mathrm{L}$ active chlorine should be applied with FRC concentration of 5.58 and $9.92 \mathrm{mg} / \mathrm{L}$, respectively. After 48 hours of chlorine exposure, bacteria development could be noted in all treatments except at chlorine concentration of $50 \mathrm{mg} / \mathrm{L}$ (FRC $4 \mathrm{mg} / \mathrm{L}$ ) in pond water with TSS of $69 \mathrm{mg} / \mathrm{L}$ and chlorine concentration of 30 to $50 \mathrm{mg} /$ $\mathrm{L}$ (FRC 1.58 and $12.28 \mathrm{mg} / \mathrm{L}$ ) in pond water with TSS of $29 \mathrm{mg} / \mathrm{L}$. The number of bacteria number in pond water with TSS of $29 \mathrm{mg} / \mathrm{L}$ was significantly lower than in pond water with TSS of 69 and $114 \mathrm{mg} / \mathrm{L}$ $(P<0.01)$. Complete bacterial inactivation could still be noted in chlorine concentration of $50 \mathrm{mg} / \mathrm{L}$ (FRC $4.56 \mathrm{mg} / \mathrm{L}$ ) in pond water with TSS of $29 \mathrm{mg} / \mathrm{L}$ after 96 hours exposure time

Measurement of other water quality parameters (Figure 5) revealed that total organic carbon (TOC) concentration in TSS 69 and $114 \mathrm{mg} / \mathrm{L}$ immediately after chlorine application was about $15.80 \mathrm{mg} / \mathrm{L}$ and

TSS $29 \mathrm{mg} / \mathrm{L}$

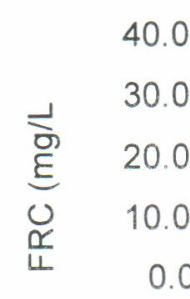

40.00

\subsection{0}

20.00

10.00

0.00

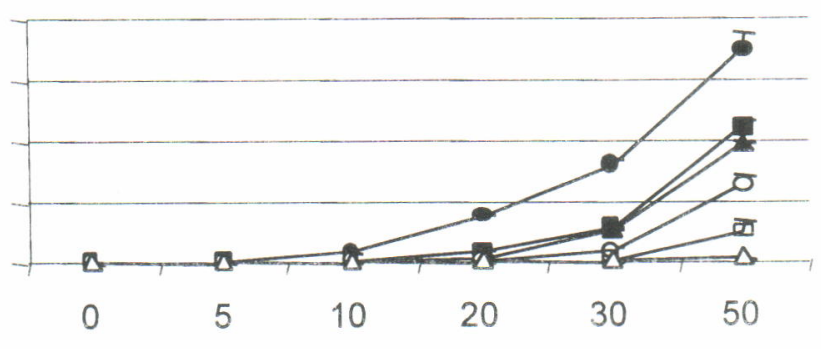

Active chlorine (mg/L)

TSS $69 \mathrm{mg} / \mathrm{L}$
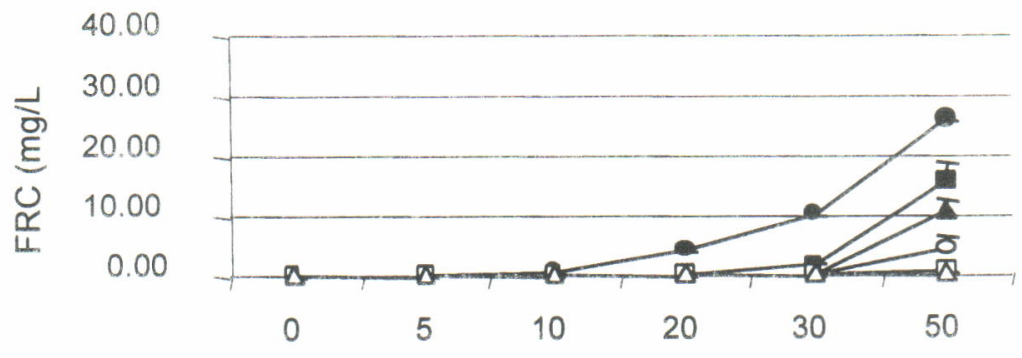

Active chlorine (mg/L)

TSS $114 \mathrm{mg} / \mathrm{L}$
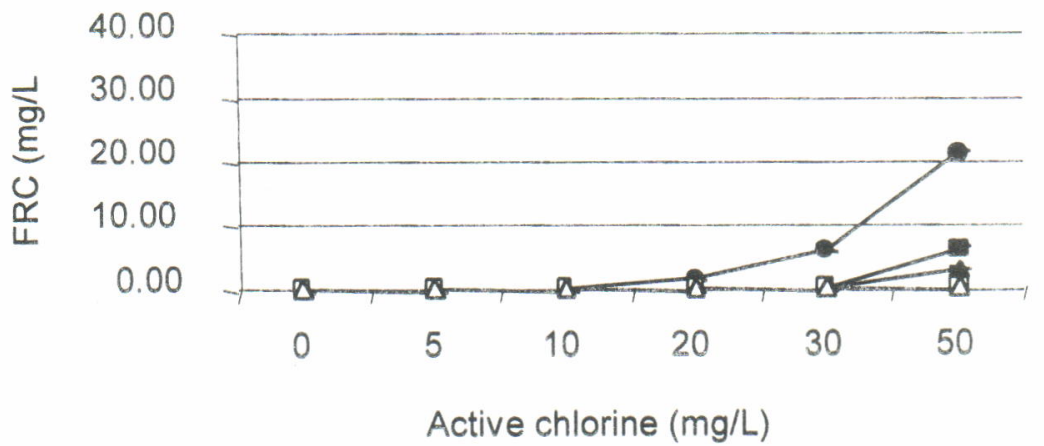
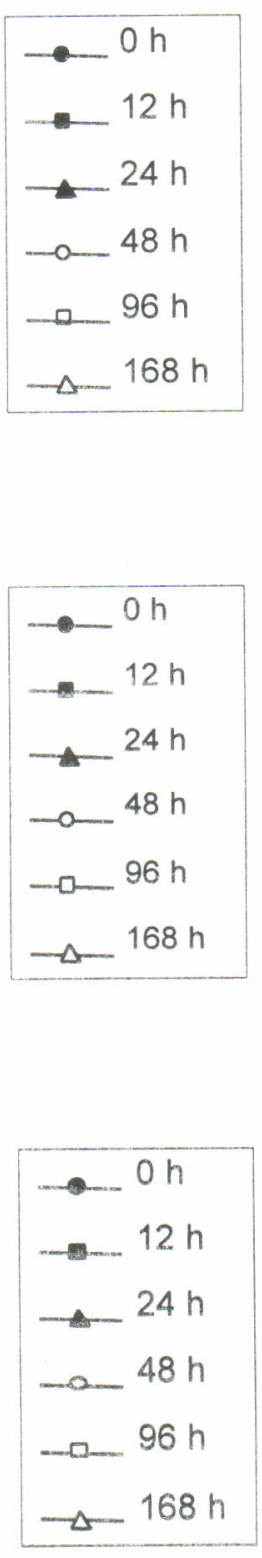

Figure 1. Free residual chlorine (FRC) of different total suspended solid (TSS) concentrations of shrimp pond water treated with different chlorine concentrations. Bars represent standard error 
TSS $29 \mathrm{mg} / \mathrm{L}$

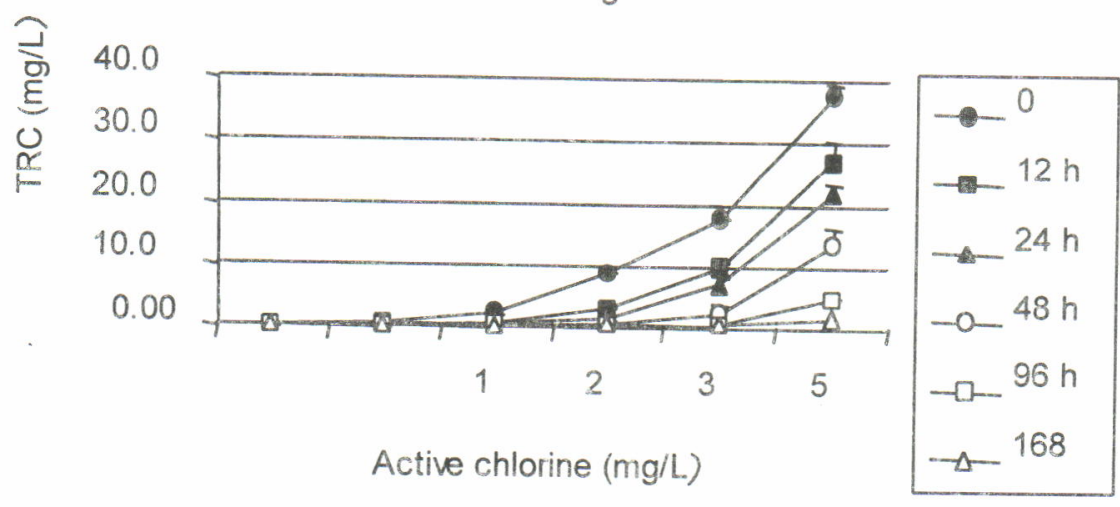

TSS $69 \mathrm{mg} / \mathrm{L}$

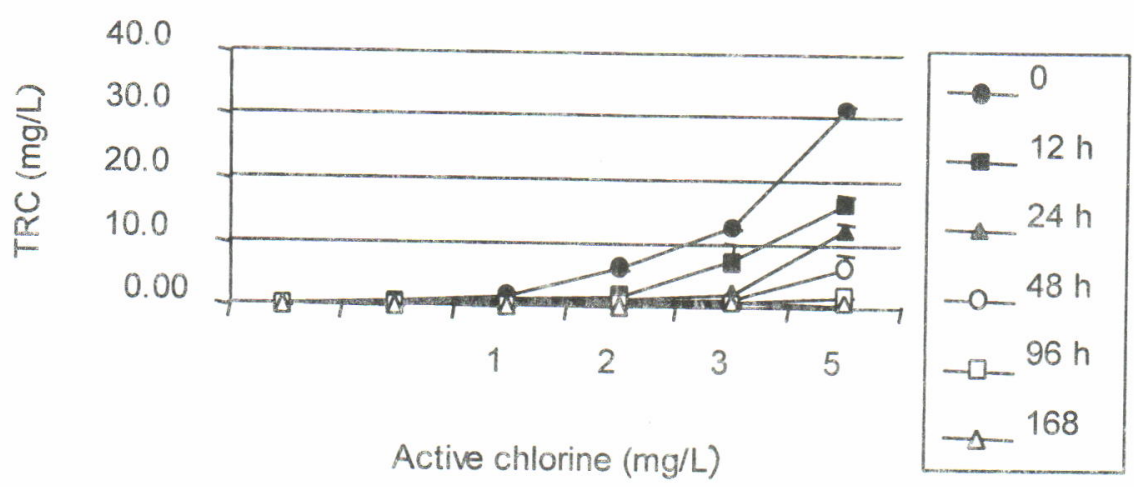

TSS $114 \mathrm{mg} / \mathrm{L}$

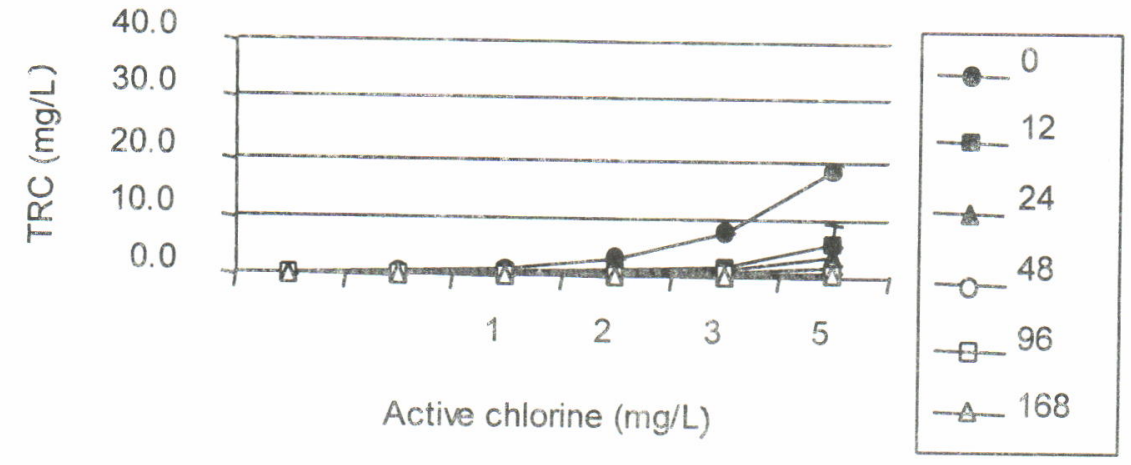

Figure 2. Total residual chlorine (TRC) of different total suspended solid (TSS) concentrations of shrimp pond water treated with different chlorine concentrations. Bars represent standard error

significantly higher than in TSS of $29 \mathrm{mg} / \mathrm{L}(P<0.01)$ which was $9.25 \mathrm{mg} / \mathrm{L}$. On the other hand, no significant difference was observed among chlorine concentrations both immediately and 168 hours after chlorine application

A significant difference was also observed in total ammonia nitrogen content. Total ammonia concentration immediately after chlorine was applied in pond water with TSS of $29 \mathrm{mg} / \mathrm{L}$ was significantly lower than in pond water with TSS of 69 and $114 \mathrm{mg} / \mathrm{L}$ $(P<0.01)$, and was lower in high chlorine concentration $(50 \mathrm{mg} / \mathrm{L})$ than in the lower concentration of 20 $\mathrm{mg} / \mathrm{L}$. After 168 hours of chlorine exposure, total ammonia in pond water with TSS of $69 \mathrm{mg} / \mathrm{L}$ was higher than in pond water with TSS of $29 \mathrm{mg} / \mathrm{L}$ and $114 \mathrm{mg} /$ L. No total ammonia variation was detected among chlorine concentrations. This might relate to no difference in bacterial density among the chlorine treat- 
TSS $29 \mathrm{mg} / \mathrm{L}$

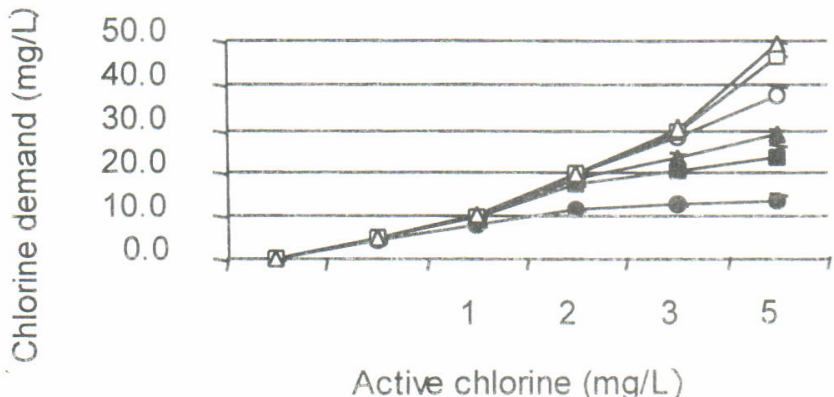

Active chlorine $(\mathrm{mg} / \mathrm{L}$ )

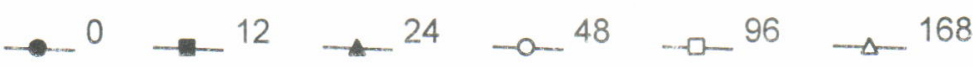

TSS $69 \mathrm{mg} / \mathrm{L}$.
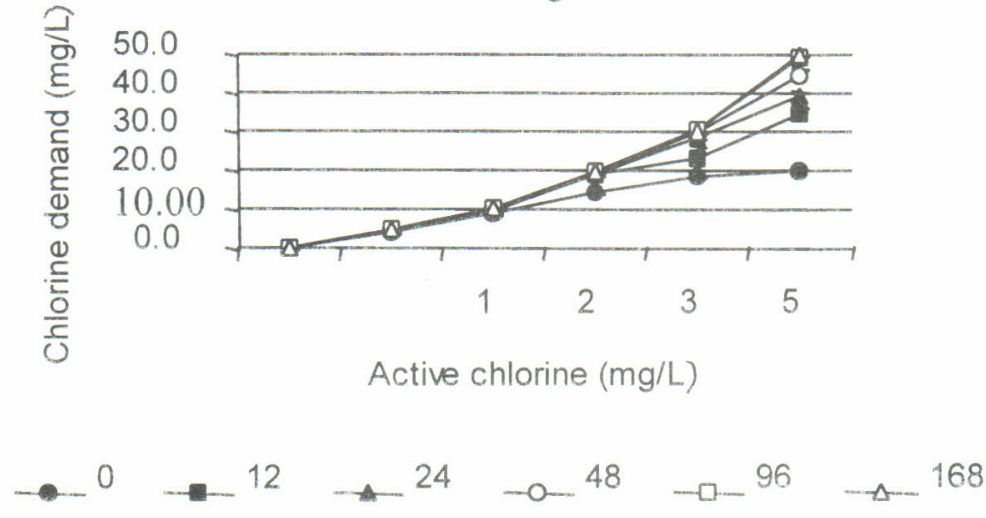

TSS $114 \mathrm{mg} / \mathrm{L}$

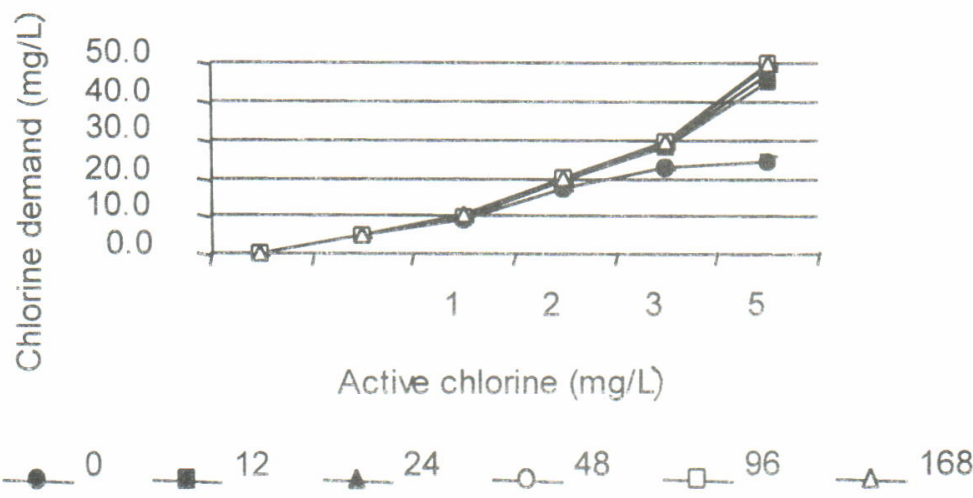

Figure 3. Chlorine demand of different total suspended solid (TSS) concentrations of shrimp pond water treated with different chlorine concentrations. Bars represent standard error

ments as a result of very low free residual chlorine concentration 168 hours after chlorine exposure.

A clear pattern was observed in $\mathrm{pH}$ value (Figure 6). Water $\mathrm{pH}$ in pond water with TSS of $114 \mathrm{mg} / \mathrm{L}$ immediately and after 168 hours chlorine application was lower than in pond water with TSS of 69 and 29 $\mathrm{mg} / \mathrm{L}(\mathrm{P}<0.01)$. Among chlorine concentrations, chlorine at a concentration of 20 to $50 \mathrm{mg} / \mathrm{L}$. after 0 -hour chlorine exposure had higher water $\mathrm{pH}$ than in control and in chlorine concentrations of 5 to $10 \mathrm{mg} / \mathrm{L}$. After 168 hours of chlorine exposure, a significantly higher water $\mathrm{pH}$ was found in high chlorine concentration compared to in chlorine concentration of $5 \mathrm{mg} / \mathrm{L}$. 
TSS $29 \mathrm{mg} / \mathrm{L}$

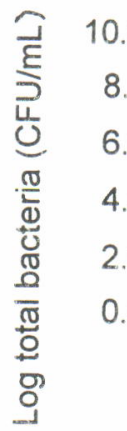

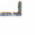

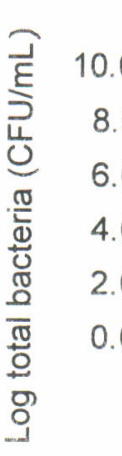

10.0
8.0
6.0
4.0
2.0
0.0

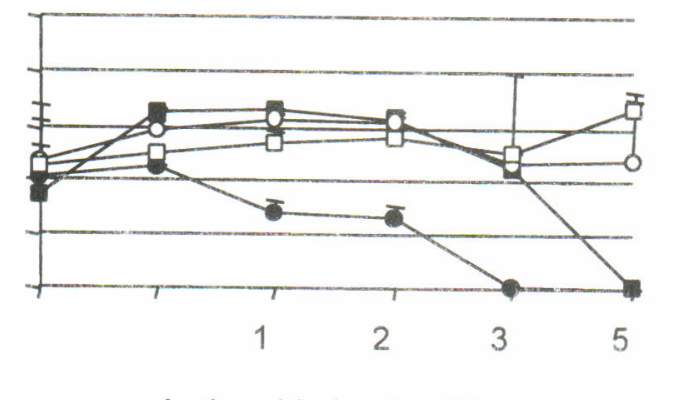

Active chlorine (mg/L)

TSS $114 \mathrm{mg} / \mathrm{L}$

है
है
$\frac{1}{0}$
$\frac{0}{0}$
$\frac{0}{0}$
$\frac{0}{0}$
$\frac{0}{0}$
0
0
0
0

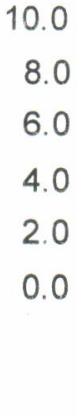

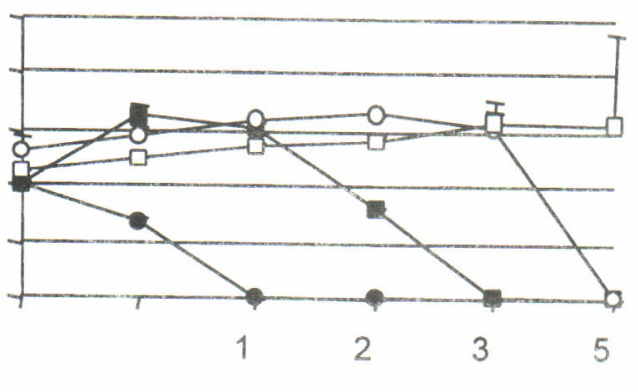

Active chlorine (mg/L)

TSS $69 \mathrm{mg} / \mathrm{L}$.
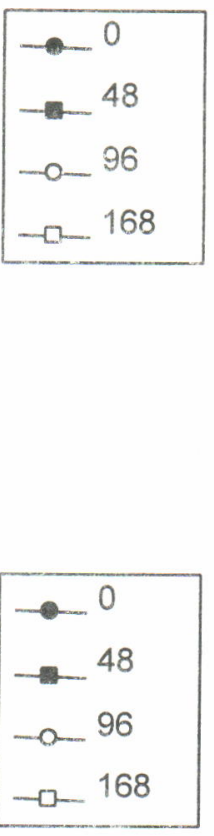

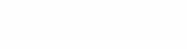



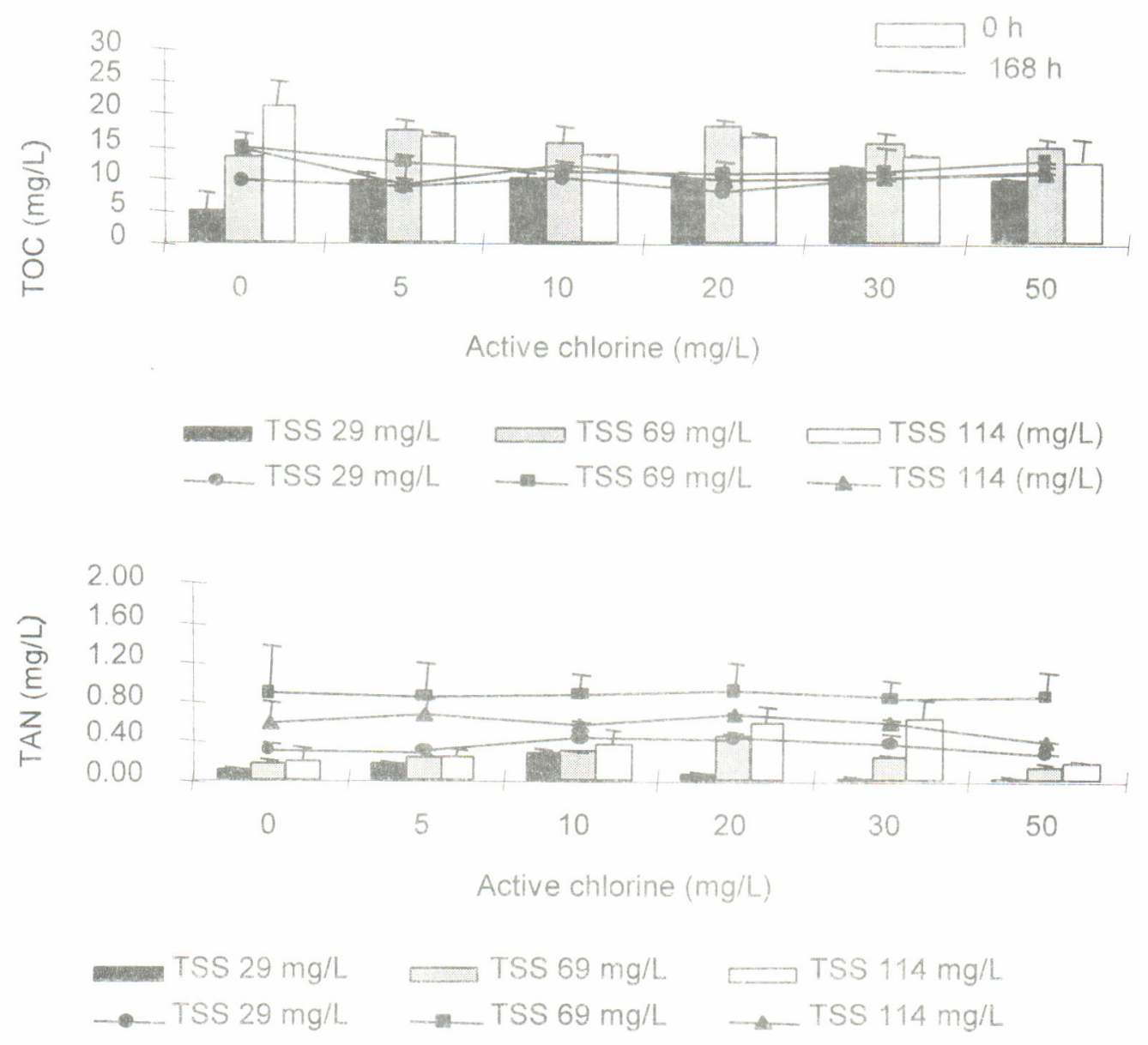

Figure 5. Total organic carbon (TOC) and total ammonia nitrogen (TAN) of different total suspended solid (TSS) concentrations of shrimp pond water treated with different chlorine concentrations. Bars represent standard error

hours, the concentration of active chlorine applied has to be more than 10 to $30 \mathrm{mg} / \mathrm{L}$ for pond water with TSS concentration of 29 and $69 \mathrm{mg} / \mathrm{L}$ respectively, and $50 \mathrm{mg} / \mathrm{L}$ for pond water with TSS of $114 \mathrm{mg} / \mathrm{L}$. Compared to pond water with TSS of 69 and $114 \mathrm{mg} /$ $\mathrm{L}$, application of active chlorine at concentration of 50 $\mathrm{mg} / \mathrm{L}$ in pond water with TSS concentration of $29 \mathrm{mg} /$ $L$ could maintain the free residual chlorine at concentration recommended for a longer period of 96 hours.

Present study shows that bacteria inactivation correlates with the presence of free and total residual chlorine concentration rather than with the concentration of active chlorine applied. In order to get a complete bacteria inactivation, concentrations of free and total residual chlorine in water have to be more than 1.0 and $2.17 \mathrm{mg} / \mathrm{L}$, respectively, which are higher than those suggested by Boyd (1996). The experiment also indicated that although complete bacterial inactivation was reached, bacterial growth would resume when concentrations of free and total residual chlorine decreased below the concentration mentioned earlier.

In addition to free and total residual chlorine, bacterial inactivation also depended on the presence of TSS concentration. TSS not only increases the demand on chlorine but may also protect the bacteria from the disinfectant (Harakeh, 1986). This notion is in accordance with the results of this experiment. Higher concentrations of free and residual chlorine were needed to inactivate bacteria in 2.5 and 3.5 month-old ponds with TSS concentration of 69 and $114 \mathrm{mg} / \mathrm{L}$ than in 16-day-old pond water with TSS of $29 \mathrm{mg} / \mathrm{L}$. Observations immediately after chlorine application $(\mathrm{O}$ h) showed that free and total residual chlorine at concentrations of 1.16 and $2.40 \mathrm{mg} / \mathrm{L} \mathrm{com-}$ pletely inactivated bacteria in 16-day-old pond water but it did not produce the same effects in 2.5 and 3.5-month-old ponds. 


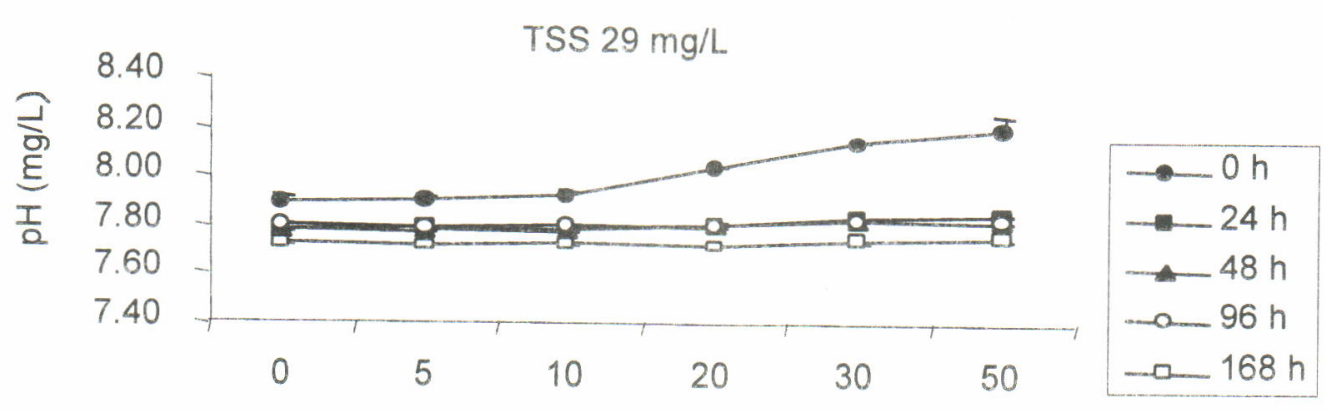

Active chlorine $(\mathrm{mg} / \mathrm{L})$
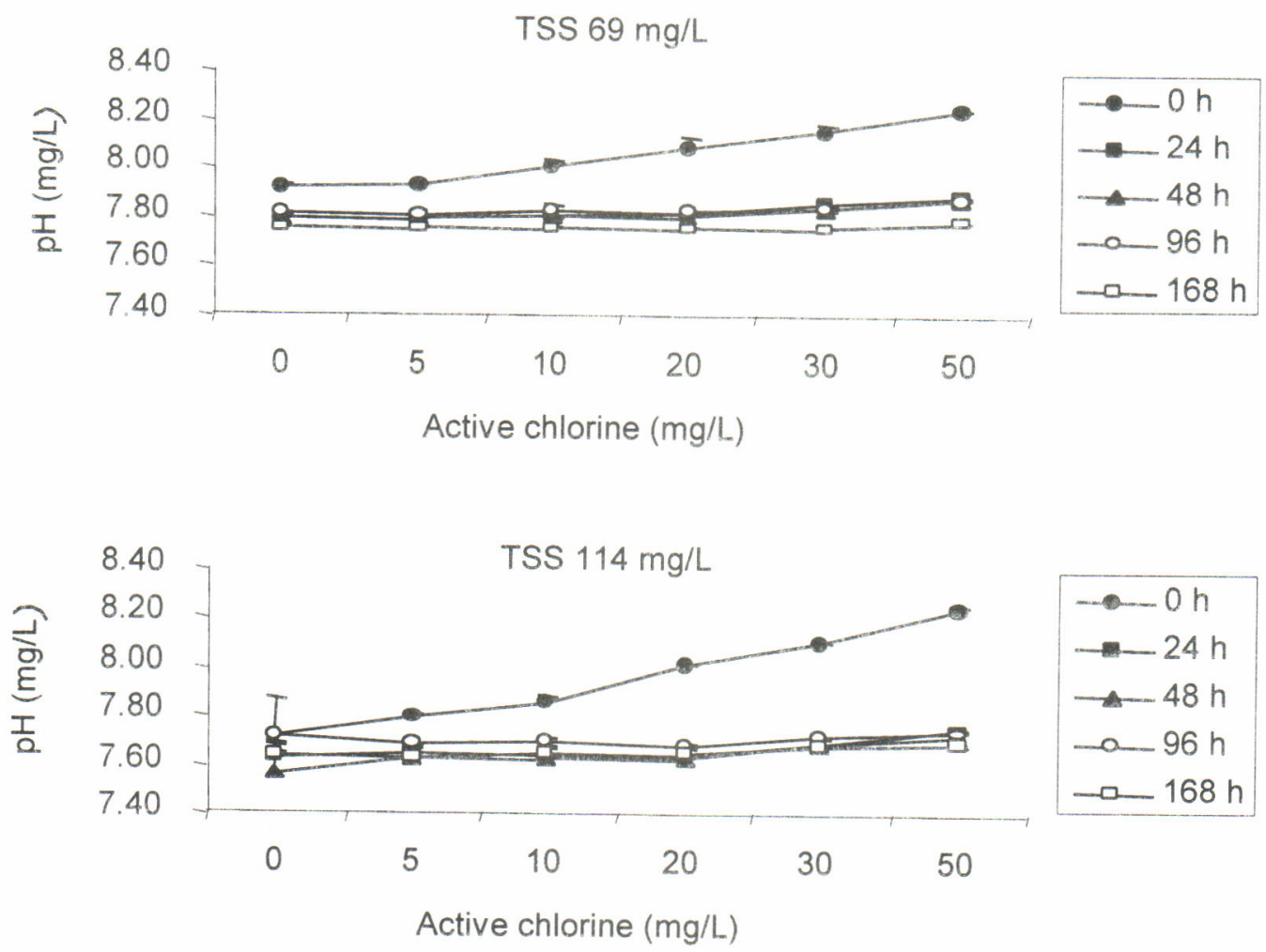

Figure 6. pH of different total suspended solid (TSS) concentrations of shrimp pond water treated with different chlorine concentrations. Bars represent standard error

Chlorine demand and bacterial inactivation of shrimp pond water were significantly affected by the initial chlorine concentration, TSS concentration and duration of chlorine exposure. To obtain FRC within the concentration which effectively inactivates total bacteria in 24 hours, the initial chlorine concentration applied has to be more than 10 and $30 \mathrm{mg} / \mathrm{L}$ for shrimp pond water with TSS concentration of 29 and $69 \mathrm{mg} /$ $L$, respectively. While for shrimp pond water with TSS concentration of $114 \mathrm{mg} / \mathrm{L}$, higher concentration of 50 $\mathrm{mg} / \mathrm{L}$ should be used.

\section{ACKNOWLEDGMENT}

The author would like to thank Prof. C. Kwei Lin for comments and suggestions concerning the ex- periment and Ms. Sari Virgawati for assistance in this study.

\section{REFERENCES}

Archer, A., E. Fischer, R. Turnheim, and Y. Manor. 1997. Ecologically friendly wastewater disinfection techniques. Water Research, 31(6):1398-1404.

American Public Health Association (APHA). 1992. Standard methods for the examination of water and wastewater. Greenberg, A.E., L.S., Clesceri, A.D. Eaton (eds.). Byrd Pre Press. Springfield. USA.

Box, G.E.P., W.G. Hunter, and J.S. Hunter. 1978. Statistic for experimenters: An introduction to design, data analysis, and model building. John Wiley and Sons, Inc. $653 \mathrm{pp}$. 
Boyd, C.E. 1996. Chlorination and water quality in aquaculture ponds. World Aquaculture, 27: 41-45

Boyd, C.E., and L., Massaut. 1999. Risks associated with the use of chemicals in pond aquaculture. Aquacultural Engineering, 20: 113-132.

Chanratchakool P. (1995) White patch disease of black tiger shrimp (Penaeus monodon). Aquatic Animal Health Research Institute (AAHRI) Newsletter 4(1), 3.

Dierberg, F.E. and W. Kiattisimkul. 1996. Issue, impacts, and implications of shrimp aquaculture in Thailand. Environmental Management, 20(5):649-666.

Harakeh, M.S. 1986. Factors influencing chlorine disinfection of wastewater effluent contaminated by rotaviruses, enteroviruses and bacteriophages. In
Water Chlorination: Chemistry, Environmental Impact and Health Effects, vol.4, R. L. Jolley, R.J. Bull, W.P. Davis, S. Katz, M.H.Robert Jr and V.A. Jacobs (eds.). Lewis Publisher, Inc. p.681-690.

Hedge, A., Anthony, J., and Rao, S. 1996. Inactivation of viruses in aquaculture systems. Infofish International 6, 40-43.

Hopkin, J.S., R.D. Hamilton II, P.A. Sandifer, C.L. Browdy, and A.D. Stokes. 1993. Effect of water exchange rate on production, water quality, effluent characteristics and nitrogen budgets of intensive shrimp ponds. Journal of the World Aquaculture Society, 24 (3): 304320.

Kongkeo, H. 1995. How Thailand made it to the top. Infofish International 1, 25-31. 